\title{
RESEARCH
}

Open Access

\section{Field application of bio-control agents and aqueous plant extracts for controlling bacterial soft rot and enhancement yield quality of Solanum tuberosum L. CV. Diamond}

Tarek G. Abdel-Gaied ${ }^{1 *}$, Maurice S. Mikhail², Ahmed I. Abdel-Alim², Hamdy I. Seif El-Nasr ${ }^{2}$ and Hassan Abd El-Khair ${ }^{1}$

\begin{abstract}
Background: Application of chemical bactericides, for controlling soft rot bacteria, causes environmental pollution and toxic hazards to human. In addition, it is ineffective, expensive, and limited. Therefore, application of bio-control agents, plant extracts, or safe chemicals may play an important role as safe alternative approaches for controlling phyto-pathogenic bacteria.

Objective: This work is aimed to apply bio-control agents (Bacillus subtilis, Bacillus pumilus, Trichoderma harzianum, and Trichoderma virens), aqueous plant extracts (lantana flowers and leaves, lemongrass leaves, and olive cake), and citric acid as pre-sowing treatment for controlling bacterial soft rot pathogen and study their ability for improving yield and quality of potato tubers in field and storage. All treatments were applied as soil treatment and/or foliar spray, except citric acid applied as foliar spray only.

Results: The cultural filtrates of bio-control agents of B. subtilis, B. pumilus, T. harzianum, and T. virens; aqueous plant extracts of lantana, lemongrass, and olive cake; and citric acid could protect daughter potato tubers against bacterial soft rot disease in field application, except lemongrass (as soil treatment). The bio-control agents highly increased the activities of peroxidase, polyphenol oxidase, and chitinase enzymes, than other treatments. The biocontrol agents also improved the shoot parameters, viz, shoot length, number of shoots/pit, and number of leaves/ pit and yield parameters, viz, tuber weight/pit, tubers number/pit, and total tubers weight/pit, compared to citric acid and plant extracts, respectively. The treatments as foliar spray have good results for protecting the potato tubers through storage, than soil treatment. The treatments highly enhanced the stored potato tubers quality, viz, dry matter, reducing sugars, total carbohydrates, specific gravity, and starch content.

Conclusions: The tested treatments could protect the potato tubers in field and/or storage against soften development. The treatments could improve the plant growth and yield parameters in field as well as enhanced the stored potato tubers quality and increase the stored time. It is clear that the treatments can be applied as presowing treatment for controlling Erwinia soft rot bacteria.
\end{abstract}

Keywords: Field application, Bacteria soft rot, Pre-sowing treatments, Storage, Safe treatments

\footnotetext{
* Correspondence: tgommaa@yahoo.com

${ }^{1}$ Plant pathology Dept., National Research Centre, Dokki, Giza, Egypt

Full list of author information is available at the end of the article
}

() The Author(s). 2020 Open Access This article is licensed under a Creative Commons Attribution 4.0 International License, which permits use, sharing, adaptation, distribution and reproduction in any medium or format, as long as you give appropriate credit to the original author(s) and the source, provide a link to the Creative Commons licence, and indicate if changes were made. The images or other third party material in this article are included in the article's Creative Commons licence, unless indicated otherwise in a credit line to the material. If material is not included in the article's Creative Commons licence and your intended use is not permitted by statutory regulation or exceeds the permitted use, you will need to obtain permission directly from the copyright holder. To view a copy of this licence, visit http://creativecommons.org/licenses/by/4.0/. 


\section{Background}

Erwinia carotovora subsp. carotovora, the causal agent of soft rot disease, is one of the worldwide destructive bacterial pathogen in vegetables including potato (Solanum tuberosum L.). The disease may occur on potato tubers in the field, in transit, and in storage causing economic damage to tuber yield reaching up to 2, 10 , and $60 \%$, respectively. Soft rot bacterium can live as epiphyte and endophyte on plant debris or as saprophyte in soil. Then, the bacterium could penetrate the plant host through wounds or natural openings (Makhlouf-Abeer and Abdeen, 2014; Viswanath et al. 2018). The bacterium can release enzymes of cellulase, protease, pectate lyase, polygalacturanase, and pectin-methylesterase which degrade the plant cell wall. The bacterium has the widest host range of many economically important vegetables including eggplant, cabbage, carrot, Chinese cabbage, cucumber, garlic cloves, onion bulbs, pepper, potato tubers, radish roots, squash, sweet potato, and tomato (Bhat et al. 2012). Application of chemical bactericides for controlling soft rot bacteria is ineffective and their usefulness for disinfecting of potato tubers is limited. In addition, it is ineffective and expensive and had harmful effect to environment and human health (Van der Wolf and de Boer 2007). Therefore, application of bio-control agents, aqueous plant extracts, or safe chemicals may play an important role as safe alternative approaches for controlling soft rot pathogen.

Field application of Trichoderma harzianum and $\mathrm{Ba}$ cillus subtilis could prevent the development of soft rot disease in daughter potato tubers, when applied as presowing treatments. The treatments also increased the plant growth parameters of potato (Abd-El-Khair and Haggag 2007). The strongest antagonistic activity against E. carotovora subsp. carotovora was obtained by application of Trichoderma viride, Peudomonas fluorescens, and B. subtilis combined with chitosans, respectively, where all treatments also could reduce the soft rot development until 20-week storage (Makhlouf and Abdeen 2014). Application of aqueous plant extract of neem leaves or seeds (Bdliya and Dahiru, 2006) as well as mahogany bark (Bdliya and Abraham 2010) significantly reduced the incidence and severity of soften disease in potato tubers under artificially inoculation conditions. The Jute leaf extract significantly protected the treated potatoes until 22 weeks against soft rot development in storage (Rahman et al. 2012). Aqueous plant extracts of lemongrass, garlic, aloe vera, and neem had the greatest inhibitory effects against Erwinia sp. (Simeon and Abubaker 2014). The cold water leaf extract of neem has the most inhibitive against E. carotovora using agar diffusion method (Ijato 2016). Immersion of potato tubers in aqueous solutions (1\%) of each citric, acetic, ascorbic, or malonic acid alone significantly reduced the soft rot symptoms (Bartz and Kelman 1986). Acetic acid or boric acid showed the bactericidal activity against $P$. carotovorum subsp. carotovorum in vitro tests. All treatments significantly decreased the infection rate or weight loss. Boric acid was the most effective in controlling the soft rot disease of potato in storage, than acetic acid (Rahman et al. 2017).

This work is aimed to study the bactericide effects of four of bio-control agents (Bacillus subtilis, Bacillus pumilus, Trichoderma harzianum, and Trichoderma virens), three of Egyptian plant species [lantana flowers and leaves (Lantana camara L.), lemongrass leaves (Cymbopogon citrates L), and olive cake (Olea europaea L.)], and citric acid, against soft rot pathogen. All treatments were applied at pre-sowing as soil treatment or foliar spray, except citric acid was applied as foliar spray only. The ability of applied treatments for protecting daughter potato tubers and improving the growth and potato tuber yield in field as well as reducing soft rot incidence in stored potato tubers and enhancing their quality was studied.

\section{Methods}

\section{Antibacterial treatments}

Two of rhizobacteria, i.e., B. subtilis and B. pumilus, and two Trichoderma spp., i.e., T. harzianum and T. virens, were obtained from Plant Pathology Dept., National Research Centre, Egypt; three of Egyptian plant species, viz, lantana, lemongrass, and olive cake, were applied as soil treatment and/or foliar spray, while citric acid as safe chemical was applied as foliar spray treatment only.

\section{Preparation of cultural filtrates of bio-control agents}

For preparation of cultural filtrates of bacterial biocontrol agents, nutrient glucose $(2 \%)$ broth [peptone $5 \mathrm{~g}$, beef extract $3 \mathrm{~g}$, glucose $20 \mathrm{~g}$, distilled water $1 \mathrm{~L}, \mathrm{pH} 7.2$ ] was prepared and sterilized in conical flasks. A medium flask was separately inoculated with $1 \mathrm{ml}$ of 48 -h-old culture of each B. subtilis and B. pumilus. Then, the inoculated flasks were incubated at $30 \pm 2{ }^{\circ} \mathrm{C}$ for $48 \mathrm{~h}$. The antagonistic bacterial cells were centrifuged at 4500 rpm for $15 \mathrm{~min}$, and then, the supernatant was filtered through filter paper (Whatman no.1). The cultural filtrates were sterilized by filtration through sterile 0.45 $\mu \mathrm{m}$ membrane filter (cellulose nitrate, Whatman). Then, the crude supernatant of each bacterial antagonist was kept at $-20{ }^{\circ} \mathrm{C}$ until used (Tshikalange et al. 2005).

For preparation of cultural filtrates of Trichoderma spp., Martin medium [glucose $10 \mathrm{~g}$, peptone $5 \mathrm{~g}$, $\mathrm{KH}_{2} \mathrm{PO}_{4} 1 \mathrm{~g}, \mathrm{MgSO}_{4} 0.5 \mathrm{~g}$, Rose Bengal $30 \mu \mathrm{g}$, streptomycin $0.03 \mathrm{~g}$, distilled water $1 \mathrm{~L}]$ was prepared and sterilized in conical flasks. The medium flask was separately inoculated with 1-cm-diameter disc of 1-week-old culture of each Trichoderma spp. The inoculated flasks 
were incubated at $30 \pm 2{ }^{\circ} \mathrm{C}$ for 1 week. Then, the Trichoderma spp. propagules were filtered through filter paper (Whatman no. 1). The cultural filtrates were sterilized by filtration through sterile $0.45-\mu \mathrm{m}$ membrane filter (cellulose nitrate, Whatman), and then, the crude supernatant of each Trichoderma spp. stored as mentioned before (Tshikalange et al. 2005).

\section{Preparation of aqueous plant extracts}

Cold water extraction method was applied for plant extract preparation. The dried parts of each plant species were firstly grinded into powder using a hand grinder, and then, about $20 \mathrm{~g}$ of each plant material was separately soaked in $100-\mathrm{ml}$ sterilized distilled water in 250 $\mathrm{ml}$ conical flask overnight in a refrigerator. Then, the aqueous plant extract was firstly filtered through doublelayered muslin cloth twice in conical flasks, and then, each plant extract was sterilized by filtration through sterile $0.45-\mu \mathrm{m}$ membrane filter (cellulose nitrate, Whatman). All aqueous plant extracts were stored as mentioned before until used (Tshikalange et al. 2005)

\section{Field experiments}

Field experiment, in a randomized complete design, was conducted at El-Kanater, Kalubiya Governorate, Egypt, during the summer growing season (February-May, 2017) for testing of different materials. All treatments were applied at pre-sowing in field. The field experiment was subjected to under naturally infection with $E$. carotovora subsp. carotovora. Field experiment (66 plots) consisted of small plots $4 \mathrm{~m}^{2}(2 \times 2 \mathrm{~m})$ in an area with three replicates (plots) was applied for each treatment as well as the controls. Each plot consisted of four lines, where each line included six pits (24 pits/plot). In soil treatments, B. subtilis, B. pumilus, T. harzianum, and T. virens were applied at $50-\mathrm{ml}$ antagonist filtrate in sowing hole, while aqueous plant extract of each lantana, lemongrass, and olive cake were applied at the rate of $50 \mathrm{ml}$ in sowing hole. In foliar spray, the same above treatments were applied at 3-4 leaf growth stage of plant at rate of 50-ml antagonist filtrate or 50-ml plant extract per $1 \mathrm{~m}^{2}$ of area. Citric acid was applied at $50 \mathrm{ml}$ of solution $10 \%$ per $1 \mathrm{~m}^{2}$ of area. For controls, PDB or NB media were applied. One tuber-piece cv. Diamond containing one or more sprouts was sown in each pit. Irrigation and fertilization were carried out as recommended. Effect of the tested materials was recorded on:

\section{Soft rot incidence}

The incidence of soft rot was recorded as percentages of soften daughter potato tubers' weight to whole tubers' weight in each treatment at harvest time according to the modified formula described by Abd-El-Khair and Haggag (2007).

Soften incidence $\%=\frac{\text { Soften potato tuber weight }}{\text { Whole of potato tubers weight }} \times 100$

\section{Enzymatic plant activity}

Six potato plants were randomly chosen from each treatment as well as controls after 2 months of sowing. Potato leaves were kept in ice box and then transferred to the laboratory for enzymatic activity studies. Leaf tissue $(5 \mathrm{~g})$ was homogenized with $0.2 \mathrm{M}$ Tris $\mathrm{HCl}$ buffer $(\mathrm{pH}$ 7.8) containing $14 \mathrm{mM} \mathrm{B}$-mercaptoethanol at the rate of $1 / 3 \mathrm{~W} / \mathrm{V}$. The homogenate was centrifuged at $3000 \mathrm{rpm}$ for $15 \mathrm{~min}$. The supernatant was applied to determine enzyme activities (Tuzun et al. 1989).

Peroxidase (POD) Peroxidase activity was determined by incubation of 0.1 of plant extract with $4 \mathrm{ml}$ of guaiacol for $15 \mathrm{~min}$ at $25{ }^{\circ} \mathrm{C}$. The guaiacol solution consisted of $3 \mathrm{ml}$ of $0.05 \mathrm{M}$ potassium phosphate (pH 5.7), $0.5 \mathrm{ml}$ of guaiacol $2 \%$, and $0.5 \mathrm{ml}$ of $\mathrm{H}_{2} \mathrm{O}_{2} 0.3 \%$. Peroxidase activity was expressed as the increase in absorbance at 470 nm (Abeles et al. 1971).

Polyphenol oxidase (PPO) The activity of polyphenol oxidase was determined using the method described by Matta and Dimond (1963). The reaction mixture contained $0.1 \mathrm{ml}$ of plant extract, $0.5 \mathrm{ml}$ of $0.3 \mathrm{M}$ potassium phosphate (pH 6.5), and $0.1 \mathrm{ml}$ of 3(3,4-dihydrooxyphenyl)-L-alanine (L-DOPA) brought to a final volume of 3.0 $\mathrm{ml}$ with distilled water. The activity of polyphenol oxidase was expressed as the increase in absorbance at 475 nm (Morsy 2005).

Chitinase (Ch) Colloidal chitin was prepared from chitin powder (Sigma Co.) according to the method described by Ried and Ogryd-Ziak (1981). About $20 \mathrm{~g}$ of chitin powder suspended in $250 \mathrm{ml}$ of phosphoric acid (85\%) was stored at $4{ }^{\circ} \mathrm{C}$ for $24 \mathrm{~h}$, and then, they were blended in 21 of distilled water using an awning blender. The suspension was centrifuged. This washing procedure was repeated twice. The colloidal chitin suspension was adjusted to $\mathrm{pH} 7$ with $1 \mathrm{~N} \mathrm{NaOH}$ and recentrifuged. The pelleted colloidal chitin was stored at 4 ${ }^{\circ} \mathrm{C}$ until used. One milliliter of colloidal chitin was added to $3 \mathrm{ml}$ of $0.05 \mathrm{M}$ citrate phosphate buffer (pH 6.6) in test tubes. One milliliter of plant extract was added and mixed by shaking. Tubes were incubated in water bath at $37{ }^{\circ} \mathrm{C}$ for $60 \mathrm{~min}$, then cooled and centrifuged before assaying. Reducing sugars were determined in $1 \mathrm{ml}$ of the supernatant by adding $1 \mathrm{ml}$ of dinitro-salysilic acid 
(DAS) solution. After boiling to $5 \mathrm{~min}$, the optical density was determined at $540 \mathrm{~nm}$ (Monreal and Reese 1969).

\section{Plant growth and yield parameters}

Six potato plants were randomly chosen from each treatment as well as controls after 60 days of sowing. Effect of the aforementioned materials on the averages of plant growth parameters, i.e., shoot length/pit, number of shoots/pit, and number of leaves/pit, was recorded. At harvest time, the averages of yield parameters, i.e., tuber weight/pit, tuber number/pit, and the total tuber weight/ pit, were recorded.

\section{Storage experiment}

After harvest, potato tuber yield of six potato pits were separately collected from field experiment, where potato tubers with no visible soft rot symptoms were chosen. Then, the potato tubers of each treatment were separately stored in plastic net. Three plastic nets were employed as replicates for each treatment as well as the controls. The tubers' weight in each plastic net was recorded in the beginning of experiment. The potato tubers were stored for 3 months at room temperature.

\section{Effect on soft rot incidence}

Stored potato tubers were weekly assayed for development of soft rot incidence according to the modified formula described by Abd-El-Khair and Haggag (2007).

Soften incidence $\%=\frac{\text { Initial weight of tubers-weight of healthy tubers }}{\text { Initial weight of tubers }} \times 100$

\section{Effect on quality of stored potato tubers}

Dry matter content Dry matter content of stored potato tubers was determined at $65{ }^{\circ} \mathrm{C}$ for $72 \mathrm{~h}$ using the standard methods as illustrated by AOAC (1990).

Reducing sugars Total reducing sugars of stored potato tubers were extracted by ethanol $(80 \%)$, then water replaced ethanol, and lead acetate was clarified. The excess of the lead acetate was precipitated by sodium oxalate. Reducing total sugars were determined in the clarified solution as described by Shaffer and Hartman (1921). The non-reducing sugars were calculated from the difference between the percentage of reducing sugars and total sugars.

Determination of total carbohydrates Total carbohydrates of stored potato tubers were determined according to the method described by Dubois et al. (1956). About $5 \mathrm{ml}$ of sulfuric acid (67\%) was added to $0.1 \mathrm{~g}$ of the dry matter of potato tuber in a test tube. One hour later, the volume was completed to $100 \mathrm{ml}$ with distilled water and the solution was filtered. One milliliter of the filtrate was pipetted into a test tube, and then, $1 \mathrm{ml}$ of aqueous phenol solution (5\%) was added to the solution, followed by $5 \mathrm{ml}$ of concentrated sulfuric acid from a fast delivering pipette. Measurements of the color intensity were taken by using a spectrophotometer at $490 \mathrm{~nm}$, and the content was calculated from the standard curve of pure glucose.

Specific gravity Tuber specific gravity of stored potato tubers of stored potato tubers was calculated from the sample weight in air and water.

Starch content The specific gravity of stored potato tubers was used to calculate the starch amount as methods described by Butron (1948).

\section{Statistical analysis}

Data were subjected to analysis of variance using Computer Statistical Package (CO-STATE) User Manual Version 3.03, Barkley Co., USA. The means were compared at $5 \%$ level of probability by Duncan's new multiple range test (Snedecor and Cochran 1980).

\section{Results \\ Field experiment \\ Effect of soft rot incidence}

Results revealed that the cultural filtrates of bio-control agents, viz, B. subtilis, B. pumilus, T. harzianum, or $T$. virens, and aqueous extracts of lantana, lemongrass, or olive cake (as soil treatments or foliar spray treatments) as well as citric acid (as foliar spray treatment) could protect the daughter tubers against naturally soft rot infection, where no soft rot symptoms were recorded at harvest time, except NB medium only and lemongrass (as soil treatment) which show the percentages of soft rot incidence about 20.4 and $17.9 \%$, respectively.

\section{Effects on plant enzymatic activity}

In soil treatment, the cultural filtrates of bio-control agents could increase the activity of POD, PPO, and Ch enzymes in the ranges of 214-222\%, 292-1047\%, and $342-633 \%$, where rhizo-bacteria highly increased the activity of tested enzymes, than Trichoderma spp., respectively. Aqueous plant extracts could increase the activity of POD, PPO, and Ch enzymes in the ranges of $151-152 \%$, $239-292 \%$, and $267-317 \%$, respectively. Lemongrass, olive cake, and lantana highly increased the POD activity, while lantana, lemongrass, and olive cake highly increased the PPO and Ch enzymes, respectively (Table 1).

In foliar spray, the cultural filtrates of bio-control agents increased the activity of POD, PPO, and Ch enzymes in the ranges of $89-116 \%, 255-453 \%$, and $379-$ 
Table 1 Effect of bio-control agents, aqueous plant extracts, and citric acid as soil treatment and/or foliar spray on plant enzyme activity of peroxidase, polyphenol oxidase, and chitinase in field application

\begin{tabular}{|c|c|c|c|c|c|c|c|c|c|c|c|c|}
\hline \multirow[t]{4}{*}{ Treatments } & \multicolumn{12}{|c|}{ Plant enzymatic activity } \\
\hline & \multicolumn{6}{|c|}{ Soil treatment } & \multicolumn{6}{|c|}{ Foliar spray } \\
\hline & \multicolumn{2}{|c|}{ Peroxidase } & \multicolumn{2}{|c|}{ Polyphenol oxidase } & \multicolumn{2}{|l|}{ Chitinase } & \multicolumn{2}{|c|}{ Peroxidase } & \multicolumn{2}{|c|}{ Polyphenol oxidase } & \multicolumn{2}{|l|}{ Chitinase } \\
\hline & OD & Incr.\% & OD & Incr.\% & $\mathrm{OD}$ & Incr.\% & OD & Incr.\% & OD & Incr.\% & $\mathrm{OD}$ & Incr.\% \\
\hline Bacillus subtilis & $2.711 a^{*}$ & 222 & $0.413 a$ & 1047 & $0.088 a$ & 633 & $2.300 a b c$ & 89 & $0.210 a$ & 453 & $0.067 \mathrm{cde}$ & 379 \\
\hline Bacillus pumilus & $2.675 \mathrm{a}$ & 218 & $0.164 a$ & 356 & $0.078 a b$ & 550 & $2.583 a b$ & 112 & $0.195 a$ & 413 & $0.103 b c$ & 636 \\
\hline Trichoderma harzianum & $2.638 \mathrm{a}$ & 214 & $0.147 \mathrm{bc}$ & 308 & $0.077 a b$ & 542 & $2.634 a$ & 116 & $0.187 a$ & 392 & $0.070 \mathrm{~cd}$ & 400 \\
\hline Trichoderma virens & $2.665 \mathrm{a}$ & 217 & $0.141 \mathrm{bc}$ & 292 & $0.053 a b c$ & 342 & $2.609 a$ & 114 & $0.135 \mathrm{bcd}$ & 255 & $0.106 b c$ & 657 \\
\hline Lantana & $2.051 \mathrm{~b}$ & 144 & $0.141 b c$ & 292 & $0.050 \mathrm{bc}$ & 317 & $2.106 \mathrm{bcd}$ & 73 & $0.128 \mathrm{~cd}$ & 237 & 0.017 ef & 21 \\
\hline Lemongrass & $2.117 \mathrm{~b}$ & 152 & $0.122 \mathrm{bc}$ & 239 & $0.048 \mathrm{bc}$ & 300 & 1.934cde & 59 & $0.165 a b c$ & 334 & $0.133 b$ & 850 \\
\hline Olive cake & $2.107 \mathrm{~b}$ & 151 & $0.126 b c$ & 250 & $0.044 c$ & 267 & 2.053cde & 69 & $0.183 a b$ & 382 & $0.064 \mathrm{cdef}$ & 357 \\
\hline Citric acid & NT & & & & & & $2.197 a b c$ & 80 & $0.202 a$ & 432 & $0.221 a$ & 1479 \\
\hline PDB medium only & $1.494 \mathrm{C}$ & 78 & $0.106 b c$ & 194 & $0.043 \mathrm{~cd}$ & 258 & 1.635def & 34 & $0.054 \mathrm{e}$ & 42 & $0.026 \mathrm{def}$ & 86 \\
\hline NB medium only & $1.665 \mathrm{c}$ & 98 & $0.107 b c$ & 197 & $0.035 \mathrm{~cd}$ & 192 & $1.609 a$ & 32 & 0.086de & 126 & $0.030 \mathrm{def}$ & 114 \\
\hline Control & $0.840 \mathrm{~d}$ & - & $0.036 c$ & - & $0.012 d$ & - & $1.218 \mathrm{f}$ & - & $0.038 \mathrm{e}$ & - & $0.014 f$ & - \\
\hline
\end{tabular}

NT not test

*Means in each column followed by different letter(s) are significantly different according to Duncan's multiple range test at $P \leq 0.05$

657\%. Trichoderma spp. highly increased the POD activity than rhizo-bacteria, while rhizo-bacteria highly increased the activity of PPO and Ch enzymes, than Trichoderma spp., respectively. Aqueous plant extracts increased the activity of POD, PPO, and Ch enzymes in the ranges of $59-73 \%, 237-382 \%$, and $21-580 \%$, respectively. Lantana, lemongrass, and olive cake highly increased the POD enzyme; olive cake, lemongrass, and lantana increased the activity of PPO enzyme, while olive cake, lemongrass, and lantana highly increased $\mathrm{Ch}$ enzyme, respectively (Table 1 ).

\section{Plant growth parameters}

In soil treatment, the cultural filtrates of bio-control agents increased the shoot length (SL) in the ranges of 50.3-54.1\%, where Trichoderma spp. highly increased SL than rhizo-bacteria, respectively. The cultural filtrates of bio-control agents increased the shoot number $(\mathrm{SN})$ in the ranges of $100.0-200.0 \%$, where $T$. virens had highly increased the $\mathrm{SN}$, than B. pumilus, B. subtilis, and T. harzianum, respectively. The same treatments increased the leaf number (LN) in the ranges of $247.9-287.4 \%$, where $T$. virens had highly increased, than $B$. pumilus, $T$. harzianum, and B. subtilis, respectively. Aqueous plant extracts increased the growth parameters, e.g., SL, SN, and $\mathrm{LN}$, in the ranges of $35.2-52.2 \%, 60.0-140.0 \%$, and $105.2-201.0 \%$, respectively. Lantana highly increased all shoot parameters, followed by olive cake and lemongrass, respectively (Table 2).

In foliar spray, the cultural filtrates of bio-control agents increased the SL in the ranges of 58.7-69.4\%, where rhizo-bacteria highly increased the shoot length, than Trichoderma spp., respectively. The SN of potato was increased in the ranges of $16.3-62.8 \%$, while LN increased in the ranges of $76.2-126.7 \%$ when applied of cultural filtrates of bio-control agents. B. pumilus had highly increased the two growth parameters, than other agents. Applications of aqueous plant extracts increased $\mathrm{SL}, \mathrm{SN}$, and $\mathrm{LN}$ in the ranges of $62.5-75.0 \%, 42.2-44.6 \%$, and $108.9-120.8 \%$ with aqueous plant extracts. Olive cake highly increased SL and LN, while lantana highly increased SN, respectively. The above plant growth parameters were $41.2,66.7$, and $78.2 \%$ with citric acid when applied as foliar spray only, respectively (Table 2 ).

\section{Yield parameters}

In soil treatment, the average of potato tuber weight increased in the ranges of $17.2-65.1 \%$ with antagonistic, where Trichoderma spp. highly increased tuber weight, than rhizo-bacteria, respectively. Aqueous plant extracts increased the tuber weight averages in the ranges of $10.0-26.9 \%$, where lemongrass had highly increase tuber weight, followed by lantana and olive cake. The potato tuber number per pit was increased in the ranges of 17.2-65.1\% with bio-control agents, where Trichoderma spp. showed highly increased potato number, than rhizo-bacteria. The tuber number ranged from 27.9 to $67.4 \%$ with aqueous plant extracts, where lemongrass, followed by lantana and olive cake highly increased the potato number, respectively. The total tuber yield per pit ranged from 79.7 to $93.2 \%$ with bio-control agents, compared to $43.4-88.2 \%$ with aqueous extracts. B. sutilis, followed by $T$. harzianum, T. virens, and B. pumilus, while aqueous extracts of lantana, followed by 
Table 2 Effect of bio-control agents, aqueous plant extracts, and citric acid as soil treatments and/or foliar spray on shoot parameters of potato plants in field application

\begin{tabular}{|c|c|c|c|c|c|c|c|c|c|c|c|c|}
\hline \multirow[t]{3}{*}{ Treatments } & \multicolumn{6}{|c|}{ Soil treatment } & \multicolumn{6}{|c|}{ Foliar spray } \\
\hline & \multicolumn{2}{|c|}{ Shoot length } & \multicolumn{2}{|c|}{ Shoot no./pit } & \multicolumn{2}{|c|}{ Leaves no./pit } & \multicolumn{2}{|c|}{ Shoot length } & \multicolumn{2}{|c|}{ Shoot no./pit } & \multicolumn{2}{|c|}{ Leaves no./pit } \\
\hline & $\mathrm{cm}$ & Incr.\% & No. & Incr.\% & No. & Incr. \%. & $\mathrm{cm}$ & Incr.\% & No. & $\operatorname{lncr} . \%$ & No. & Incr.\% \\
\hline Bacillus subtilis & $47.8 a^{*}$ & 50.3 & $2.6 a b$ & 160.0 & $66.8 \mathrm{a}$ & 247.9 & $53.8 \mathrm{a}$ & 68.1 & 2.0abcd & 62.8 & $39.8 \mathrm{a}$ & 97.0 \\
\hline Bacillus pumilus & $48.2 \mathrm{a}$ & 51.6 & $2.8 a b$ & 180.0 & $73.4 a$ & 282.3 & $54.2 \mathrm{a}$ & 69.4 & $2.6 a$ & 20.9 & $45.8 \mathrm{a}$ & 126.7 \\
\hline Trichoderma harzianum & $49.0 \mathrm{a}$ & 54.1 & $2.0 \mathrm{~b}$ & 100.0 & $72.8 a$ & 279.2 & $50.8 a b$ & 58.7 & $2.4 a b$ & 16.3 & $38.8 a b$ & 92.1 \\
\hline Trichoderma virens & $48.4 a$ & 52.2 & $3.0 \mathrm{a}$ & 200.0 & $73.8 \mathrm{a}$ & 287.4 & $51.6 a b$ & 61.2 & $2.2 a b c$ & 16.3 & 35.6abc & 76.2 \\
\hline Lantana & $48.4 a$ & 52.2 & $2.4 a b$ & 140.0 & $57.8 \mathrm{ab}$ & 201.0 & $52.0 \mathrm{a}$ & 62.5 & $1.6 \mathrm{bcd}$ & 67.4 & $42.2 \mathrm{a}$ & 108.9 \\
\hline Lemongrass & 43.0ab & 35.2 & $1.6 b c$ & 60.0 & $39.4 b$ & 105.2 & $53.6 a$ & 67.5 & $2.4 a b$ & 27.9 & $42.8 \mathrm{a}$ & 111.9 \\
\hline Olive cake & $46.6 a$ & 46.5 & $2.2 a b$ & 120.0 & $46.0 \mathrm{~b}$ & 139.6 & $56.0 \mathrm{a}$ & 75.0 & $1.4 \mathrm{~cd}$ & 27.9 & $44.6 a$ & 120.8 \\
\hline Citric acid & NT & & & & & & $45.2 b$ & 41.2 & 2.0abcd & 66.7 & 36.0abc & 78.2 \\
\hline PDB medium only & $35.6 b c$ & 11.9 & $1.3 b c$ & 30.0 & $24.8 b c$ & 26.3 & $36.8 c$ & 15.0 & $1.3 \mathrm{~cd}$ & 8.3 & $27.4 \mathrm{~cd}$ & 45.6 \\
\hline NB medium only & $35.6 b c$ & 11.9 & $1.4 b c$ & 40.0 & $26.4 b c$ & 37.5 & $35.8 \mathrm{c}$ & 11.9 & $1.3 \mathrm{~cd}$ & 8.3 & $28.4 \mathrm{bcd}$ & 40.6 \\
\hline Control & $31.8 \mathrm{c}$ & - & $1.0 \mathrm{c}$ & - & $19.2 \mathrm{C}$ & - & $32.0 \mathrm{c}$ & - & $1.2 \mathrm{~d}$ & - & $20.2 d$ & - \\
\hline
\end{tabular}

\section{NT not test}

*Means in each column followed by different letter(s) are significantly different according to Duncan's multiple range test at $P \leq 0.05$

lemongrass and olive cakes highly increased the yield of potato tubers, respectively (Table 3 ).

In foliar spray, the averages of potato tuber weight/pit were in the ranges of $71.4-104.0 \%$ when applied the cultural filtrates of antagonistic, and it was in the ranges of $11.2-41.6 \%$ with aqueous plant extracts application, compared to $39.9 \%$ with citric acid, respectively. The cultural filtrates of antagonistic highly increased tuber weight average, than others. The potato tuber number per pit was increased in the ranges of $23.8-54.8 \%$ with cultural filtrates of bio-control agents, while it was ranged from 26.2 to $59.5 \% \%$ with aqueous plant extracts, compared to $59.5 \%$ with citric acid, respectively. T. harzianum and lemongrass highly increased the potato tuber number parameters, than others. The total tuber yield per pit ranged from 126.8 to $178.6 \%$ with cultural filtrates of bio-control agents, where $T$. virens and $B$. subtilis highly increased the total tubers yield, than B. pumilus and $T$. harzianum, respectively. The yield per plant was in the ranges of $50.8-117.3 \%$ with aqueous plant extracts, compared to $125.1 \%$ citric acid, respectively. Olive cake highly increased the yield, than lemongrass and lantana, respectively (Table 3 ).

Table 3 Effect of bio-control agents, aqueous plant extracts, and citric acid as soil treatment and/or foliar spray on yield parameters of potato plants in field application

\begin{tabular}{|c|c|c|c|c|c|c|c|c|c|c|c|c|}
\hline \multirow[t]{3}{*}{ Treatments } & \multicolumn{6}{|c|}{ Soil treatment } & \multicolumn{6}{|c|}{ Foliar spray } \\
\hline & \multicolumn{2}{|c|}{ Tuber weight/pit } & \multicolumn{2}{|c|}{ Tuber no./pit } & \multicolumn{2}{|c|}{ total yield /pit } & \multicolumn{2}{|c|}{ Tuber weight/pit } & \multicolumn{2}{|c|}{ Tuber no./pit } & \multicolumn{2}{|c|}{ Total yield /pit } \\
\hline & $g$ & Incr.\% & No. & Incr.\% & $\mathrm{g}$ & Incr.\% & $g$ & Incr.\% & No. & Incr.\% & $g$ & Incr.\% \\
\hline Bacillus subtilis & $83.7 b c^{*}$ & 17.2 & $7.0 \mathrm{ab}$ & 17.2 & $590.5 a$ & 93.2 & $146.3 a$ & 104.0 & $5.3 \mathrm{bcd}$ & 26.2 & $753.1 \mathrm{ab}$ & 154.9 \\
\hline Bacillus pumilus & 101.1ab & 40.4 & $5.2 \mathrm{C}$ & 40.4 & $549.3 a$ & 79.7 & $138.7 a b$ & 93.4 & $5.2 \mathrm{bcd}$ & 23.8 & $709.1 \mathrm{bc}$ & 140.0 \\
\hline Trichoderma harzianum & $119.5 a$ & 65.1 & $5.0 \mathrm{C}$ & 65.1 & $581.2 \mathrm{a}$ & 90.1 & $122.9 b$ & 71.4 & $5.7 a b c$ & 35.7 & $669.9 \mathrm{bc}$ & 126.8 \\
\hline Trichoderma virens & 118.0a & 63.9 & $5.0 \mathrm{c}$ & 63.9 & $557.2 \mathrm{a}$ & 82.3 & $130.5 \mathrm{ab}$ & 82.0 & $6.5 a$ & 54.8 & $822.9 a$ & 178.6 \\
\hline Lantana & $83.6 b c$ & 16.7 & $7.2 \mathrm{a}$ & 16.7 & $575.3 a$ & 88.2 & $84.7 \mathrm{~cd}$ & 18.1 & $5.3 \mathrm{bcd}$ & 26.2 & 445.4de & 50.8 \\
\hline Lemongrass & $91.4 b c$ & 26.9 & $5.5 b c$ & 26.9 & $506.1 \mathrm{ab}$ & 65.6 & $79.7 d$ & 11.2 & $6.7 a$ & 59.5 & $529.4 d$ & 79.2 \\
\hline Olive cake & $79.2 \mathrm{bc}$ & 10.0 & $5.5 b c$ & 10.0 & 438.4abc & 43.4 & $101.5 c$ & 41.6 & $6.3 a b$ & 50.0 & $641.9 c$ & 117.3 \\
\hline Citric acid & NT & & & & & & $100.3 c$ & 39.9 & $6.7 a$ & 59.5 & $667.6 \mathrm{bc}$ & 125.1 \\
\hline PDB medium only & $74.6 c$ & 2.6 & $4.5 c$ & 2.6 & $335.8 \mathrm{bc}$ & 9.8 & $74.8 \mathrm{~d}$ & 4.3 & $4.6 \mathrm{~cd}$ & 9.5 & 344.3ef & 16.6 \\
\hline NB medium only & $80.8 \mathrm{bc}$ & 8.8 & $4.5 c$ & 8.8 & $363.5 b c$ & 18.9 & $75 . \mathrm{od}$ & 4.6 & $4.7 \mathrm{a}$ & 11.9 & 352.6ef & 19.4 \\
\hline Control & $72.0 \mathrm{c}$ & - & $4.3 c$ & - & $305.7 c$ & - & $71.7 d$ & - & $4.2 d$ & & $295.4 f$ & - \\
\hline
\end{tabular}




\section{Storage experiment \\ Effect on soft rot incidence}

In soil treatment, the cultural filtrates of B. subtilis and B. pumilus could protect the stored potato tubers against soft rot development for the 1st month of storage, and then, the soften incidence reached up to 9.3 and $28.3 \%$ at the 12th week, respectively. On the other hands, the cultural filtrates of $T$. harzianum and $T$. virens could protect the stored potato tubers for the 1st and 2nd weeks, and then, the soften incidence reached up to 27.2 and $31.8 \%$ at the 12 th week, respectively. Aqueous extracts of lantana and lemongrass protected potato tubers for the 4th week, while olive cake could protect tuber for the 1st week, where soften incidence reached up to 21.1, 40.2, and $21.5 \%$ at the 12 th week, respectively (Table 4 ).

In foliar spray, the cultural filtrates of B. subtilis and B. pumilus protected the stored potato tubers for the 1st and 11th weeks, where the soften incidence reached up to 30.5 and $17.0 \%$ at the 12 th week, respectively. The cultural filtrates of $T$. virens could protect the potato tubers until the 2nd week, while the cultural filtrates of $T$. harzianum protected the potato tubers for the 3rd week, and then, soften incidence reached up to 25.4 and $18.8 \%$ at the 12th week. The aqueous extract of lantana protected the potato tubers until the 6th week, and the disease soften incidence was $18.1 \%$ at the 12 th week of storage. Lemongrass and olive cake aqueous extract protected the stored potato tubers until the 4th week, where disease incidence was 8.8 and $28.1 \%$ at the 12 th week, respectively. Citric acid protected the stored potato tubers until the 4th week of storage, and then, the soft rot incidence was $14.3 \%$ at the 12 th week of storage (Table 5 ).

\section{Effect on quality of stored potato tubers}

In soil treatment, the percentages of dry matter were in the ranges of $20.8-23.6 \%$ with cultural filtrates of bio- control agents, while it was in the ranges of $19.7-25.1 \%$ in stored potato tubers treated aqueous plant extracts, compared to $18.5 \%$ in untreated control, respectively. The reducing sugars in the ranges of $46.4-50.3 \mathrm{mg} / 100 \mathrm{~g}$ was significantly increased with cultural filtrates of biocontrol agents, while it was in the ranges of 41.2-44.5 $\mathrm{mg} / 100 \mathrm{~g}$, compared to $51.5 \mathrm{mg} / 100 \mathrm{~g}$ in untreated control, respectively. The total carbohydrates in stored potato tubers were in the ranges of $38.6-43.0 \%$ with cultural filtrates of bio-control agents, while in the ranges $43.3-49.7 \%$ with aqueous plant extracts, compared to $35.0 \%$, respectively. The bio-agents increased the specific gravity which was in the ranges of 1.04-1.08 $\mathrm{g} / \mathrm{cm}^{3}$ in stored potato tubers with cultural filtrates of bio-control agents, while it was in the ranges were in the ranges of $1.02-1.08 \mathrm{~g} / \mathrm{cm}^{3}$ with the aqueous plant extracts, compared to $1.02 \mathrm{~g} / \mathrm{cm}^{3}$ in untreated control, respectively. The starch content was in the ranges of 41.8-49.4\% in storage potato tubers with cultural filtrates of bio-control agents, and it ranged from 48.2 to $49.7 \%$ with aqueous plant extracts, compared to $45.9 \%$ in untreated control, respectively (Table 6).

In foliar spray, the dry matter of stored potato tubers was in the ranges of $20.4-22.8 \%$ with cultural filtrates of bio-control agents, while it was in the ranges of 19.7$26.0 \%$ with aqueous extracts increased, compared to $20.6 \%$ with citric acid and $18.5 \%$ in untreated control, respectively. The reducing sugars of stored potato tubers were in the ranges of $50.7 \mathrm{mg} / 100 \mathrm{~g}$ with cultural filtrates of bio-control agents, while it was in the ranges of 42.0 $44.5 \mathrm{mg} / 100 \mathrm{~g}$ with aqueous plant extracts, compared to $40.4 \mathrm{mg} / 100 \mathrm{~g}$ with citric acid and $51.5 \mathrm{mg} / 100 \mathrm{~g}$, in untreated control, respectively. The total carbohydrates in stored potato tubers were in the ranges of 36.6-49.7\% with cultural filtrates of bio-control agents, while it was in the ranges of $44.3-47.4 \%$ with aqueous plant extracts,

Table 4 Effect of bio-control agents and aqueous plant extracts as soil treatment against bacterial soften potato tubers disease (as weight losses \%) under storage conditions

\begin{tabular}{|c|c|c|c|c|c|c|c|c|c|c|c|c|}
\hline \multirow[t]{2}{*}{ Treatments } & \multicolumn{12}{|c|}{ Softening tubers (weight losses\%) at weeks } \\
\hline & $1 s t$ & 2nd & $3 r d$ & 4th & 5 th & 6th & 7 th & 8th & 9th & 10th & 11th & 12th \\
\hline Bacillus subtilis & $0 c^{*}$ & od & Oe & Oe & $9.3 e$ & $9.3 e$ & $9.3 e$ & $9.3 e$ & $9.3 \mathrm{~g}$ & $9.3 i$ & $9.3 \mathrm{~h}$ & $9.3 \mathrm{~h}$ \\
\hline Bacillus pumilus & Oc & od & Oe & of & $9.4 \mathrm{e}$ & $9.4 \mathrm{e}$ & $9.4 \mathrm{e}$ & $9.4 \mathrm{e}$ & $28.3 b$ & $28.3 c$ & $28.3 c$ & $28.3 d$ \\
\hline Trichoderma harzianum & Oc & $6.5 b$ & $6.5 d$ & $6.5 d$ & $11.2 \mathrm{bc}$ & $11.2 \mathrm{bc}$ & $11.2 \mathrm{bc}$ & $16.4 b$ & $27.2 \mathrm{C}$ & $27.2 d$ & $27.2 \mathrm{~d}$ & $27.2 \mathrm{e}$ \\
\hline Trichoderma virens & Oc & od & $7.7 \mathrm{C}$ & $7.7 \mathrm{c}$ & $11.6 b$ & $11.6 b$ & $11.6 b$ & $17.1 \mathrm{~b}$ & 17.1e & $17.1 \mathrm{~g}$ & $17.1 f$ & $31.8 \mathrm{c}$ \\
\hline Lantana & Oc & od & Oe & Oe & $10.8 b c$ & $10.8 b c$ & $10.8 b c$ & $11.5 c$ & $11.5 f$ & $11.5 \mathrm{~h}$ & $11.5 \mathrm{~g}$ & $21.1 f$ \\
\hline Lemongrass & Oc & od & Oe & Oe & $11.3 b c$ & $11.3 b c$ & $11.3 b c$ & $28.1 \mathrm{a}$ & $31.5 a$ & $31.5 b$ & $31.5 b$ & $40.2 b$ \\
\hline Olive cake & Oc & $6.9 b$ & $6.9 \mathrm{~cd}$ & $6.9 \mathrm{~cd}$ & $6.9 f$ & $6.9 f$ & $6.9 f$ & $12.1 \mathrm{C}$ & $12.1 \mathrm{f}$ & $12.1 \mathrm{~h}$ & $12.1 \mathrm{~g}$ & $21.5 f$ \\
\hline PDB medium only & $3.3 b$ & $3.3 c$ & $9.8 b$ & $9.8 b$ & 9.8de & $9.8 \mathrm{de}$ & 9.8de & $11.2 \mathrm{~cd}$ & $17.8 \mathrm{e}$ & $21.6 f$ & $27.3 d$ & $27.3 e$ \\
\hline NB medium only & $2.6 b$ & $2.6 \mathrm{c}$ & $7.6 \mathrm{c}$ & $7.6 \mathrm{C}$ & $10.5 \mathrm{~cd}$ & $10.5 \mathrm{~cd}$ & $10.5 \mathrm{~cd}$ & $10.5 d$ & $22.3 d$ & $23.4 \mathrm{e}$ & $25.2 \mathrm{e}$ & $40.5 b$ \\
\hline Control & $9.8 a$ & $9.8 \mathrm{a}$ & $11.6 a$ & $14.6 a$ & $19.2 \mathrm{a}$ & $22.5 \mathrm{a}$ & $25.5 \mathrm{a}$ & $28.8 \mathrm{a}$ & $31.6 a$ & $35.3 \mathrm{a}$ & $42.0 \mathrm{a}$ & $48.8 a$ \\
\hline
\end{tabular}

*Means in each column followed by different letter(s) are significantly different according to Duncan's multiple range test at $P \leq 0.05$ 
Table 5 Effect of bio-control agents, plant extracts, and citric acid as foliar spray against bacterial soften potato tubers disease (as weight losses \%) under storage conditions

\begin{tabular}{|c|c|c|c|c|c|c|c|c|c|c|c|c|}
\hline \multirow[t]{2}{*}{ Treatments } & \multicolumn{12}{|c|}{ Softening tubers (weight losses\%) at weeks } \\
\hline & $1 s t$ & 2nd & $3 r d$ & 4th & 5th & 6th & 7th & 8th & 9th & 10th & 11th & 12th \\
\hline Bacillus subtilis & $O d^{*}$ & $4.7 \mathrm{c}$ & $4.7 \mathrm{c}$ & $4.7 e$ & $4.7 \mathrm{~h}$ & $4.7 i$ & $4.7 i$ & $4.7 \mathrm{j}$ & $4.7 i$ & $21.0 d$ & $21.0 d$ & $30.5 c$ \\
\hline Bacillus pumilus & Od & od & 0e & Oe & Oi & $0 \mathrm{j}$ & $0 j$ & $0 \mathrm{k}$ & 0j & $0 j$ & 0j & $17.0 \mathrm{~h}$ \\
\hline Trichoderma harzianum & Od & od & Oe & $6.9 \mathrm{c}$ & $6.9 f$ & $6.9 \mathrm{~h}$ & $6.9 \mathrm{~h}$ & $6.9 i$ & $6.9 \mathrm{~h}$ & $6.9 i$ & $6.9 i$ & $18.8 f$ \\
\hline Trichoderma virens & Od & od & $6.3 b$ & $6.3 d$ & $6.3 \mathrm{~g}$ & $9.5 \mathrm{e}$ & $9.5 \mathrm{e}$ & $9.5 \mathrm{~g}$ & $14.4 f$ & 18.1e & 18.1e & $25.4 \mathrm{e}$ \\
\hline Lantana & Od & Od & 0e & of & $0 \mathrm{i}$ & $0 \mathrm{j}$ & $9.3 e$ & 13.2e & $18.1 d$ & $18.1 \mathrm{e}$ & $18.1 \mathrm{e}$ & $18.1 \mathrm{~g}$ \\
\hline Lemongrass & Od & od & Oe & Of & $8.8 \mathrm{~d}$ & $8.8 f$ & $8.8 f$ & $8.8 \mathrm{~h}$ & $8.8 \mathrm{~g}$ & $8.8 \mathrm{~h}$ & $8.8 \mathrm{~h}$ & $8.8 j$ \\
\hline Olive cake & Od & Od & 0e & Of & $12.6 \mathrm{c}$ & $12.6 \mathrm{~d}$ & $15.1 d$ & $23.6 c$ & $23.6 \mathrm{c}$ & $23.6 c$ & $23.6 c$ & $28.1 d$ \\
\hline Citric acid & Od & Od & 0e & Of & $8.1 \mathrm{e}$ & $8.1 \mathrm{~g}$ & $8.1 \mathrm{~g}$ & $10.9 f$ & $14.3 f$ & $14.3 \mathrm{~g}$ & $14.3 \mathrm{~g}$ & $14.3 i$ \\
\hline PDB medium only & $4.3 c$ & $4.3 \mathrm{c}$ & $4.3 d$ & $14.3 a$ & $14.3 b$ & $14.3 c$ & $16.2 \mathrm{C}$ & $16.2 d$ & 16.2e & $16.2 f$ & $16.2 f$ & $18.4 \mathrm{~g}$ \\
\hline NB medium only & $4.9 \mathrm{~b}$ & $4.9 \mathrm{~b}$ & $4.9 c$ & $11.2 b$ & $19.1 \mathrm{a}$ & $31.9 a$ & $31.9 a$ & $36.5 a$ & $38.6 a$ & $38.6 a$ & $40.4 b$ & $40.4 b$ \\
\hline Control & $9.8 \mathrm{a}$ & $9.8 \mathrm{a}$ & $11.6 a$ & $14.6 \mathrm{a}$ & $19.2 \mathrm{a}$ & $22.5 b$ & $25.5 b$ & $28.8 b$ & $31.6 b$ & $35.3 b$ & $42.0 \mathrm{a}$ & $48.8 \mathrm{a}$ \\
\hline
\end{tabular}

*Means in each column followed by different letter(s) are significantly different according to Duncan's multiple range test at $P \leq 0.05$

compared to $50.7 \%$ with citric acid and $35.0 \%$ in untreated control, respectively. The specific gravity was in range of $1.05-1.08 \mathrm{~g} / \mathrm{cm}^{3}$ and $1.03-1.089 \mathrm{~g} / \mathrm{cm}^{3}$ with cultural filtrates of bio-control agents and aqueous plant extracts, compared to $1.09 \mathrm{~g} / \mathrm{cm}^{3}$ with citric acid and $1.02 \mathrm{~g} / \mathrm{cm}^{3}$ in untreated control, respectively. The starch content in storage potato tubers was in the ranges of $42.3-50.8 \%$ and $50.0-50.8 \%$ with bio-control agents and aqueous plant extract, compared to $51.1 \%$ with citric acid and $45.9 \%$ in untreated control, respectively (Table 6).

\section{Discussion}

The obtained results revealed that bio-control agents, viz, B. subtilis, B. pumilus, T. harzianum, T. virens; aqueous plant extracts, viz, lemongrass, lantana, and olive cake; and citric acid protected the daughter potato

Table 6 Effect of bio-control agents, aqueous plant extracts, and citric acid as soil treatment and/or foliar spray on quality parameters of potato tubers under storage conditions

\begin{tabular}{|c|c|c|c|c|c|c|c|c|c|c|}
\hline \multirow[t]{2}{*}{ Treatments } & \multicolumn{5}{|c|}{ Soil treatments } & \multicolumn{5}{|c|}{ Foliar spray } \\
\hline & $\begin{array}{l}\text { Dry } \\
\text { matter } \\
(\%)\end{array}$ & $\begin{array}{l}\text { Reducing } \\
\text { sugars (mg/ } \\
100 \mathrm{~g} \text { ) }\end{array}$ & $\begin{array}{l}\text { Total } \\
\text { carbohydrates } \\
(\%)\end{array}$ & $\begin{array}{l}\text { Specific } \\
\text { gravity ( } \mathrm{g} / \\
\left.\mathrm{cm}^{3}\right)\end{array}$ & $\begin{array}{l}\text { Starch } \\
\text { content } \\
(\%)\end{array}$ & $\begin{array}{l}\text { Dry } \\
\text { matter } \\
(\%)\end{array}$ & $\begin{array}{l}\text { Reducing } \\
\text { sugars (mg/ } \\
100 \mathrm{~g} \text { ) }\end{array}$ & $\begin{array}{l}\text { Total } \\
\text { carbohydrates } \\
(\%)\end{array}$ & $\begin{array}{l}\text { Specific } \\
\text { gravity (g/ } \\
\left.\mathrm{cm}^{3}\right)\end{array}$ & $\begin{array}{l}\text { Starch } \\
\text { content } \\
(\%)\end{array}$ \\
\hline $\begin{array}{l}\text { Bacillus } \\
\text { subtilis }\end{array}$ & $\begin{array}{l}20.8 \\
\mathrm{~cd}^{*}\end{array}$ & 47.3de & $43.0 \mathrm{~d}$ & $1.07 a b$ & $49.4 a$ & $21.8 \mathrm{~cd}$ & $48.1 \mathrm{~b}$ & 49.7ab & $1.06 \mathrm{bc}$ & $42.3 d$ \\
\hline $\begin{array}{l}\text { Bacillus } \\
\text { pumilus }\end{array}$ & $23.2 b$ & $46.4 \mathrm{e}$ & $44.0 \mathrm{~cd}$ & $1.08 \mathrm{a}$ & 48.2ab & $22.8 \mathrm{C}$ & $46.6 c$ & $43.9 c$ & $1.08 a b$ & $50.8 \mathrm{a}$ \\
\hline $\begin{array}{l}\text { Trichoderma } \\
\text { harzianum }\end{array}$ & $23.6 b$ & $50.3 a b c$ & 36.7ef & $1.04 d$ & $43.5 \mathrm{~cd}$ & 20.4de & $50.7 a$ & 36.6ef & $1.08 a b$ & $47.6 \mathrm{BC}$ \\
\hline $\begin{array}{l}\text { Trichoderma } \\
\text { virens }\end{array}$ & $20.9 \mathrm{~cd}$ & $49.6 b c$ & $38.6 \mathrm{e}$ & $1.06 \mathrm{bc}$ & 41.8de & 20.6de & $49.5 b$ & 37.7de & $1.05 \mathrm{~cd}$ & $45.6 \mathrm{~cd}$ \\
\hline Lantana & $23.6 b$ & $41.2 \mathrm{~g}$ & $49.7 a$ & $1.08 a$ & $49.7 a$ & $26.0 a$ & $42.0 \mathrm{e}$ & $47.4 b$ & $1.08 a b$ & 50.0ab \\
\hline Lemongrass & 19.7de & $42.8 \mathrm{fg}$ & $46.4 b c$ & $1.07 a b$ & $48.2 \mathrm{ab}$ & 19.7ef & $43.7 d$ & $44.3 c$ & $1.03 \mathrm{de}$ & $50.8 a$ \\
\hline Olive cake & $25.1 \mathrm{a}$ & $44.5 f$ & $43.3 d$ & $1.02 \mathrm{e}$ & $49.4 a$ & $21.7 \mathrm{~cd}$ & $44.5 d$ & $45.0 \mathrm{C}$ & $1.09 a$ & 50.0ab \\
\hline Citric acid & NT & & & & & 20.6de & $40.4 \mathrm{e}$ & $50.7 a$ & $1.09 a$ & $51.1 \mathrm{a}$ \\
\hline $\begin{array}{l}\text { PDB } \\
\text { medium } \\
\text { only }\end{array}$ & 19.7de & $51.4 a b$ & $35.6 f$ & $1.07 a b$ & $45.4 \mathrm{C}$ & $19.4 \mathrm{ef}$ & $50.1 \mathrm{a}$ & 36.0ef & 1.03de & $48.5 \mathrm{abc}$ \\
\hline $\begin{array}{l}\text { NB medium } \\
\text { only }\end{array}$ & $21.9 c$ & $48.8 \mathrm{~cd}$ & $48.7 a b$ & $1.05 \mathrm{~cd}$ & $40.2 \mathrm{e}$ & $24.5 b$ & $48.9 b$ & $39.6 d$ & $1.07 a b c$ & $43.9 d$ \\
\hline Control & $18.5 \mathrm{e}$ & $51.5 a$ & $35.0 f$ & $1.02 \mathrm{e}$ & $45.9 b c$ & $18.5 f$ & $51.5 a$ & $35.0 f$ & $1.02 \mathrm{e}$ & $45.9 \mathrm{~cd}$ \\
\hline
\end{tabular}


tubers against soft rot infection in field application, except lemongrass as soil treatment. The bio-agents also highly increased the activity of POD, PPO, and Ch enzymes, than citric acid and plant extracts. The protective activities of bio-agents may be related with their ability in increasing of tested enzyme activities, where these enzymes play an important role as defense mechanism against soil-borne pathogens. Application of biotic or chemical agents increased the defense of plants against diseases, where resistance induction enhanced the plants health status against diseases either by application of inducers through optimized soil management techniques or by foliar application (Zeller 2006; Song et al. 2013; Tamma et al. 2011). These results are in agreement with those recorded by Caruso et al. (2001) and Nawar and Kuti (2003). They reported that the bio-control agent accumulation of some enzymes, viz, Ch, POD, and PPO, plays an important role in plant defense mechanisms against pathogen infection, where there are positive relationships between enzymatic activity and resistance development in plants.

Trichoderma spp., as soil treatments, also increased the levels of Ch, POD, and PPO enzymes activity in treated bean plants (Abd-El-Khair and Khalifa, 2010). B. subtilis and T. harzianum, as seed-coating formulation, significantly increased the growth parameters as well as increased defense-related enzymes, i.e., PPO, POD, and superoxide dismutase (SOD) activities in treated tomato seedlings (Kumar et al. 2015). The systemic induction of defense-related genes expression and significant increase in antioxidant enzyme activities of SOD, POD, catalase (CAT), PPO, and phenylalanine ammonia-lyase (PAL) could play a pivotal role in disease resistance against $E$. carotovora subsp. carotovora when applied with B. subtilis in tomato as reported by Chandrasekaran and Chun (2016). The high levels of PAL, PPO, POD, and total phenols were obtained in a single application of B. pumilus and $B$. amyloliquefaciens against $P$. carotovorum subsp. carotovorum strains after $8 \mathrm{~h}$ of application in potato (Gerayeli et al. 2017). Aqueous plant extracts of basil, chilli, castor beans, chamomile, lantana, lemongrass peppermint, and onion seeds increased the activities of Ch, PPO, and POD enzymes in bean plants (Abd-El-Khair and El-Gamal-Nadia, 2011). Plant extracts of two-leaf plants rich in bioactive phenolic compounds, olive and carob, reduced the soft rot severity by increase the activity of PAL after $7.5 \mathrm{~h}$ of application on potato tuber slices (Ouanas et al. 2017). The spent green tea extracts (SGT) were able to kill Pectobacterium spp., where it led to the significant decrease in pectin lyase, polygalcturonase, and pectin methyl esterase activity in inoculated carrots (Joe et al., 2017).

In soil treatment, the cultural filtrates of bio-control agents improved the shoot parameters, viz, length, number of shoots, and number of leaves/pit of potato plants, as well as increased the yield parameters of potato tubers, viz, tuber weight, tuber number, and total tuber weight/pit, when compared with aqueous plant extracts. The same trend was noticed with same treatments, followed by citric acid in foliar spray. These results are in agreement with those recorded by Malik et al. (2005). They reported that T. harzianum, as soil amendments, significantly increased the plant heights and weight. B. subtilis and T. album improved plant height, number of stems, and number of leaves/pit of treated potato. B. subtilis gave the best tuber yield as tuber treatments, while T. album was the best as a soil application with potatoes cv. Nicola (Abd-El-Khair and Seif El-Nasr, 2012).

Our results showed that the bio-control agents as well as aqueous plant extracts highly protected stored potato tuber in foliar spray, than soil treatment, where B. pumilus, T. harzianum, B. subtilis, and T. virens, followed by lantana, olive cake, and lemongrass, were the most effective for protecting stored potato tubers. The treatments also highly enhanced the potato tubers' quality, viz, dry matter, reducing sugars, total carbohydrates, specific gravity, and starch content .These results are in agreement with those recorded by Makhlouf-Abeer and Abdeen (2014). They reported that T. viride, P. fluorescens, and B. subtilis combined with chitosans showed a stronger antagonistic activity against $E$. carotovora subsp. carotovora, respectively, and all treatments reduced the soft rot development until 20-week storage. The Jute leaf extracts significantly protected the treated potatoes against the soft rot development until 22 weeks under storage conditions (Rahman et al. 2012). Aqueous plant extracts of Datura stramonium and Trigonella foenum graecum (seeds) and Azadirachta indica (leaves) inhibited the growth of $E$. carotovora in vitro tests (Viswanath et al. 2018). Finally, these results are in agreement with the recent trend in shifting toward safer and more ecofriendly alternatives for controlling of postharvest decays, where the use of antagonistic micro-organisms is becoming popular throughout the world. $B$. subtilis and T. harzianum are being used (Sharma et al. 2009).

\section{Conclusion}

It can be concluded that bio-control agents of Bacillus subtilis, Bacillus pumilus, Trichoderma harzianum, and Trichoderma virens and aqueous plant extracts of lantana, lemongrass, and olive cake can be applied as presowing for controlling bacterial soft rot disease caused by Erwinia carotoora subsp. carotovora in potato field. These treatments also improved the growth and yield parameters of potato plants. The treatments could protect the stored potato tubers against soften development and enhancement of the quality of potato tubers 


\section{Abbreviations}

POD: Peroxidase; PPO: Polyphenol oxidase; Ch: Chitinase; DAS: Dinitro-salysilic acid; NB: Nutrient broth; SL: Shoot length; SN: Shoot number; LN: Leaves number; SOD: Superoxide dismutase; CAT: Catalase; PAL: Phenylalanine ammonia-lyase

\section{Authors' contributions}

Prepared the materials and carried out the experiment in the open field_-TGA; supervision and reviewing the manuscript-MSM; data analysis and visualization-AIA; writing the manuscript-HIS; suggesting the problem and helped in writing the manuscript-HAE. All authors revised, read, and approved the final manuscript.

\section{Funding}

There is no funding.

\section{Availability of data and materials}

The tested bio-control agents, plant species, and bacterial soft rot pathogens are available in Egyptian environment and were identified in the laboratory.

\section{Ethics approval and consent to participate}

Not applicable.

\section{Consent for publication}

Not applicable.

\section{Competing interests}

The authors declare that they have no competing interests.

\section{Author details}

${ }^{1}$ Plant pathology Dept., National Research Centre, Dokki, Giza, Egypt. ${ }^{2}$ Plant pathology Dept., Faculty of Agriculture, Cairo University, Giza, Egypt.

Received: 19 February 2020 Accepted: 17 May 2020

Published online: 29 May 2020

\section{References}

Abd-El-Khair H, Haggag- Karima HE (2007) Application of some bactericides and bioagents for controlling the soft rot disease in potato. Res J Agricult Biolog Sci 3 (5): 463-473.

Abd-El-Khair H, El-Gamal-Nadia G (2011) Effects of aqueous extracts of some plant species against Fusarium solani and Rhizoctonia solani in Phaseolus vulgaris plants. Arch PhytopatholPlant Protection 44(1):1-16

Abd-El-Khair H, Khalifa RKhM, Haggag- Karima HE (2010) Trichoderma species on damping off diseases incidence, some plant enzymes activity and nutritional status of bean plants J Am Sci 6 (9): 486-497.

Abd-El-Khair H, Seif El-Nasr HI (2012) Applications of Bacillus subtilis and Trichoderma spp. for controlling the potato brown rot in field. Archives of Phytopathology and Plant Protection 45(1):1-15

Abeles FB, Bpsshart RB, Forrence LE, Habig WH (1971) Preparation and purification of glucanase and chitinase from bean leaves. Plant Physiol 47: 129-134

AOAC(1990) Official methods of analysis $15^{\text {th }}$ Ed.Association of official Analysis Chemists.Washington.DC.176-188.

Bartez JA, Kelman A (1986) Reducing the potential for bacterial soft rot in potato tubers by chemical treatments and drying. Am Potato J 63:481-491

Bdliya BS, Abraham P (2010) Efficacy of mahogany bark aqueous extracts and exposure to solar heat for treatment of potato tuber soft rot caused by Erwinia carotovora ssp. carotocora. J Plant Protection Res 50(3):393-397

Bdliya BS, Dahiru B (2006) Efficacy of some plant extracts on the control of potato tuber soft rot caused by Erwinia carotovora ssp. carotovora. J Plant Protection Res 46(3):285-294

Bhat KA, Bhat NA, Mohiddin FA, Sheikh PA, Wani AH (2012) Studies on pectinase activities of isolates of Erwinia carotovora and Rhizopus sp. causing soft rot in cabbage (Brassica oleracea var. capitata L). Afr J Agricult Res 7(5):6062-6067

Butron WG (1948) The potato. Chapman and Hall, London pp.3019.

Caruso C, Chilosi G, Leonard L, Bertin L, Magro P, Buonocore V, Caporale C (2001) A basic peroxidase from wheat kernel with antifungal activity. Phytochemistry 58:743-750

Chandrasekaran M, Chun SC (2016) Expression of PR-protein genes and induction of defense-related enzymes by Bacillus subtilis CBR05 in tomato (Solanum lycopersicum) plants challenged with Erwinia carotovora subsp. carotovora. Bioscience, Biotechnology and Biochemistry 80(11):2277-2283

Dubois M, Smith F, Gilles KA, Hamilton JK, Rebers PA (1956) Colorimetric method for determination of sugars and related substances. Annal Chem 28(3):350356

Gerayeli N, Ravari SB, Tarighi S (2017) Evaluation of the antagonistic potential of Bacillus strains against Pectobacterium carotovorum subsp. carotovorum and their role in the induction of resistance to potato soft rot infection. Eur J Plant Pathol. https://doi.org/10.1007/s10658-017-1344-0

ljato JY (2016) Assessment of the antibacterial activities of some aqueous plant leaf extracts against Erwinia carotovora subsp. carotovora. A soft rot bacterium of vegetables. New York Science Journal 9(9):1-3

Joe MM, Chanbhasa M, Henry AJ, Benson A (2017) Treatment of carrots with spent green tea extract reduces the soft rot of Pectobacterium spp. Arch Phytopathol Plant Protection 50(9-10):491-503

Kumar SPM, Chowdappa P, Krishna V (2015) Development of seed coating formulation using consortium of Bacillus subtilis OTPB1 and Trichoderma harzianum OTPB3 for plant growth promotion and induction of systemic resistance in field and horticultural crops. Indian Phytopath 68(1):25-31

Makhlouf-Abeer $\mathrm{H}$, Abdeen R (2014) Investigation on the effect of chemical and biological control of bacterial soft root disease of potato in storage. $J$ Biology, Agriculture and Healthcare 4(10):31-44

Malik G, Dawar S, Sattar A, Dawar A (2005) Efficacy of Trichoderma harzianum after multi-plication on different substrates in the control of root rot fungi. Int J Biol Biotechnol 291:237-242

Matta A, Dimond AE (1963) Symptoms of Fusarium within relation to quantity of fungus and enzyme activity in tomato stems. Phytopathology53:544-578.

Monreal J, Reese ET (1969) The chitinase of Sarratia marcescens. Can J Microbiol 15:689-696

Morsy KMM (2005) Induced resistance against damping-off, and wilt diseases of lentil. Egypt. J Phytopathol 33(2):53-63

Nawar H, Kuti JO (2003) Wyerone acid phytoalexin synthesis and peroxidase activity as markers for resistance of broad beans to chocolate spot disease. J Phytopathol 151(10):564-570

Ouanas S, Hamelin G, Hervetb M, Andrivon D, Val F, Zaidi RY (2017) Protection against bacterial soft rot by olive extracts is related to general defense induction in potato tubers. Plant Pathology 66:404-411

Rahman MM, Khan AA, Ali ME, Mian IH, Akanda AM, Abd Hamid SB (2012) Botanicals to control soft rot bacteria of potato. The Scientific World Journal, Vol 2012: 6 pages, Article, ID 796472

Rahman MM, Khan AA, Mian IH, Akanda AM, Alam MZ (2017) Effect of some chemicals on incidence of potato soft rot disease in Bangladesh. Bangladesh J Sci Ind Res 52(2):135-140

Ried JD, Ogryd-Ziak DM (1981) Chitinase over producing mutant of Serratia marcescens. Appl Environ Microbiol 41:664-669

Shaffer PA, Hartman AF (1921) The iodometric determination of copper and its use in sugar analysis. J Biological Chem 35(3):229-266

Sharma RR, Singh D, Singh R (2009) Biological control of postharvest diseases of fruits and vegetables by microbial antagonists: a review. Biological Control 50:205-222

Simeon AU, Abubakar A (2014) Evaluation of some plant extracts for the control of bacterial soft rot of tubers. American Journal of Experimental Agriculture 4(12):1869-1876

Snedecor GW, Cochran WG (1980). Statistical Methods. 5th ed. Ames IA: lowa State Univ Press pp. 593.

Song GC, Ryu SY, Kim YS, Lee JY, Choi JS, Ryu CM (2013) Elicitation of induced resistance against Pectobacterium carotovorum and Pseudomonas syringae by specific individual compounds derived from native Korean plant species. Molecules 18:12877-12895

Tamma L, Thüriga B, Fliessbacha A, Goltliebb AE, Karavanib S, Cohenb Y (2011) Elicitors and soil management to induce resistance against fungal plant diseases. NJAS - Wageningen Journal of Life Sciences 58:131-137

Tshikalange TE, Meyer JJM, Hussein AA (2005) Antimicrobial activity, toxicity and the isolation of a bioactive compound from plants used to treat sexually transmitted diseases. J Ethnopharmacol 96:515-519

Tuzun S, Rao MN, Vogeli U, Schardl CL, Kuc J (1989) Induced systemic resistance to blue mould; Early induction an accumulation of B-1,3glucanase, chitinase and other pathogenesis proteins (b- proteins) in immunized tobacco. Phytopathlogy 79:79-983 
Van der Wolf MJ, de Boer SH (2007) Bacterial pathogens of potato. Potato Biol Biotechnol:595-617

Viswanath HS, Bhat KA, Bhat NA, Wani TA, Mughal MN (2018) Antibacterial efficacy of aqueous plant extracts against storage soft rot of potato caused by Erwinia carotovora. Int J Curr Microbiol App Sci 7(1):2630-2639

Zeller W (2006) Status on induced resistance against plant bacterial diseases. Fitosanidad 10(2):99-103

\section{Publisher's Note}

Springer Nature remains neutral with regard to jurisdictional claims in published maps and institutional affiliations.

Submit your manuscript to a SpringerOpen ${ }^{\circ}$ journal and benefit from:

- Convenient online submission

- Rigorous peer review

- Open access: articles freely available online

- High visibility within the field

- Retaining the copyright to your article

Submit your next manuscript at $\boldsymbol{\sim}$ springeropen.com 